\title{
Genetic variability in IGFBP-3 and GH genes and their association with body weight and growth performance at birth, weaning and six-month in sheep
}

Ahmed Saleh ( $\square$ elemlak1339@gmail.com )

Southwest University https://orcid.org/0000-0003-1314-8066

Mohammed Hammoud

Alexandria University

Nasraa Dabour

Alexandria University

Elsayed Hafez

Alexandria University

Mahmoud Sharaby

Alexandria University

\section{Research Article}

Keywords: DNA sequencing, IGFBP-3, GH, RFLP, Sheep

Posted Date: October 6th, 2020

DOI: https://doi.org/10.21203/rs.3.rs-86803/v1

License: (c) (1) This work is licensed under a Creative Commons Attribution 4.0 International License.

Read Full License 


\title{
Genetic variability in IGFBP-3 and GH genes and their association with body weight and growth performance at birth, weaning and six-month in sheep
}

\author{
Ahmed. A. Saleh ${ }^{\text {a, }}{ }^{*}$, M. H. Hammoud ${ }^{\text {b }}$, Nasraa A. Dabour ${ }^{c}$, E. E. Hafez ${ }^{\text {d }}$, Mahmoud A. \\ Sharaby
}

\footnotetext{
${ }^{a}$ College of Animal Science and Technology, Southwest University, Chongqing Key Laboratory of Forage \& Herbivore, Chongqing Engineering Research Center for Herbivores Resource Protection and Utilization, Chongqing 400715 P.R. China. ${ }^{b}$ Animal and Fish Production Department -Faculty of Agriculture (Alshatby) - Alexandria University, Alexandria. Egypt ${ }^{c}$ Dairy Science and Technology Department- Faculty of Agriculture (Alshatby) - Alexandria University, Alexandria. Egypt

${ }^{d}$ Plant Protection and Bio-molecular diagnosis Department- Arid Lands Cultivation Research Institute (ALCRI) - the City of Scientific Research and Technology Applications, Alexandria. Egypt.
}

${ }^{*}$ Corresponding author

Current address: Southwest University, Beibei, Chongqing 400716, China Tel.: +86 13042317990 .

Email address: Elemlak1339@Gmail.Com 


\begin{abstract}
Body weights at birth, weaning and six-month and growth performance in lambs are economic traits that could be strongly used in sheep breeding objectives. Moreover, previous genetic studies recommended strong associations between these economic traits and polymorphisms in several candidate genes in different livestock species. The aim of this investigation was to study the polymorphism in IGFBP-3 and GH genes using DNA sequencing and RFLP, and their association with body weights and growth performance of Rahmani, Barki, Rahmani X Barki cross, Awassi/Awassi X Suffolk cross and Ossimi sheep breeds. Digestion of 654 bp for IGFBP3/HaeIII yielded only one restriction pattern of 8 fragments in all animal groups revealing the absence of polymorphism also, DNA sequencing confirmed that. While, sequencing analysis of the amplified fragment of GH gene revealed polymorphism in nucleotide sequencing, and the amino acid sequences for GH gene of Rahmani were different from those of other breeds in 4 amino acids, while, each of Rahmani X Barki cross and Ossimi amino acid sequences were different in 3 amino acids. The genetic differences in $\mathrm{GH}$ gene coincided with differences in birth, weaning and six-month weights of the breeds under study. Thus, the current results suggest that body weights and growth performance of tested sheep breeds at different stages of growth are statistically affected by GH gene which could be considered as a candidate gene for growth in breeding programs.
\end{abstract}

Keywords: DNA sequencing; IGFBP-3; GH; RFLP; Sheep

Abbreviations: IGFBP-3, Insulin-like Growth Factor Binding Protein-3 gene; GH, Growth hormone gene; RFLP, Restriction fragment length polymorphism; PCR, polymerase chain reaction; IGF, insulin-like growth factor; ADG, average daily gain; MAS, marker-assisted selection. 


\section{Introduction}

Most of the local breeds of farm animals, especially in developing countries, including sheep, suffer from the lack of genetic improvement programmes based on genetic and genomic analysis (Herd et al., 2003; Saleh et al., 2019; Saleh et al., 2020). Meanwhile, efforts in several countries are being made to intensify production systems, primarily through changing productive and reproductive management regimes and by detection of differentiation or mutations in genes that affect growth traits (Guimarães, 2007; Tester and Langridge, 2010; Lewis, 2018; Wall et al., 2018; Saleh et al., 2019; Saleh et al., 2020). Determination and characterization of the genetic differences between and within sheep breeds will help the rapid improvement of their economically important traits (Saleh, 2019a).

Moreover, to realize integrated productivity by the existing animal breeding systems, changes occurred in the growth performance of animals need to be interpreted in light of the correlated alterations in any other performance traits (Herd et al., 2003; Rachid et al., 2019). This could be achieved by utilization of appropriate production indices that incorporate precise measures of all performance traits supported by a chart for the genes controlling their behaviour (Newman, 1994). Additionally, growth traits including; birth, weaning, and six-month weights are extremely important in sheep husbandry (Rasouli et al., 2017). Consumer preference for heavier sheep with less fat has created considerable change within sheep breeding to increase weight and body size. The individuals (lambs) that grow rapidly reach market weight at a younger age, which generally means that those lambs require a limited feeding period and have a low-risk rate of death loss. With the development of biotechnology molecular biology, a more efficient and accurate selection goal could be achieved using molecular tools to explore more genes related to the behaviour of growth traits (An et al., 2011; Saleh et al., 2019).

Insulin-like Growth Factor Binding Protein-3 (IGFBP-3) and Growth Hormone (GH) genes were recently discovered to be involved in the regulation of growth traits including growth rates from birth to weaning and six-month in sheep (Hanrahan et al., 2004; Saleh, 2016; Juengel, 2018; Mazerbourg and Monget, 2018; Saleh et al., 2019). IGFBP-3 and GH genes play a key role in mammalian development, growth control, and reproduction activity as well (Currie et al., 1996; Li et al., 2008; An et al., 2011; Saleh, 2016; Rasouli et al., 2017; Saleh et al., 2019).

IGFBP-3 is a structural unique gene responsible for several effects of IGF. It plays a key role in mammalian development, growth, and reproduction (Mazerbourg and Monget, 2018; Saleh, 2019b). Single-nucleotide polymorphism (SNP) of the IGFBP-3 gene has been discovered and described in cattle and buffalo to be associated with some production traits (Maciulla et al., 1997; Saleh, 2017; Saleh, 2019b; Saleh et al., 2019). On the other side, associations have been made between few numbers of the IGFBPs and follicle status (Besnard et al., 1996; Khalid and Haresign, 1996). Moreover, due to the important role of IGFBP-3 in animal development and growth, it is considered as a candidate gene to be utilized as a marker for production and growth traits in livestock species (Ali et al., 2009; Shafey et al., 2014; Saleh et al., 2019). 
The protein encoded by GH gene, found in 1920s is a necessary member of the prolactin/somatotropin family of hormones which play a necessary role in physiological processes (Yousefi et al., 2013). GH affects cell proliferation and growth either directly or indirectly through stimulation of insulin-like growth factor (IGF) (Boyd and Bauman, 1989). In most mammals, $\mathrm{GH}$ is the product of a single gene and is generally secreted in a pulsatile manner by the pituitary gland. GH is well documented that GH influences several biological activities (Veldhuis et al., 2001) of sheep such as growth (Breier, 1999; Saleh, 2017), lactation (Baldi, 1999), reproduction (BK et al., 1995; Saleh and Zhao, 2020), metabolism (Bauman, 1999), and pregnancy (Gluckman et al., 1979). GH gene is located on chromosome 17 at the growth hormone locus. Insertion and deletions (Indels) or mutations in GH gene lead to differences in growth performance (Pereira et al., 2005). GH gene is a candidate for controlling growth in sheep since it plays a crucial role in development and growth regulation (Boyd and Bauman, 1989). A few genetic investigations on the growth of sheep breeds have concentrated on birth, weaning and yearling weights (Bathaei and Leroy, 1998; Saleh, 2017). Pereira et al., (2005) found a significant effect for the bovine GH genotype on yearling weight. Yousefi et al., (2013) observed a positive correlation between $\mathrm{GH}$ and average daily gain (ADG) from weaning to yearling in sheep and used the gene as a candidate for marker-assisted selection (MAS) in different livestock species.

According to several investigations the polymorphism in IGFBP-3 and GH effect on the mammalian growth control, development, and reproduction activity (Currie et al., 1996; Li et al., 2008; An et al., 2011; Saleh, 2016; Rasouli et al., 2017; Saleh et al., 2019; Saleh and Zhao, 2020), thus the aims of this investigation were to detect the genetic polymorphism in IGFBP-3 and GH genes by Restriction fragment length polymorphism (RFLP) and perform DNA sequencing and relating that to the diversity among some Egyptian sheep breeds for birth, weaning and six-month weights and growth performance.

\section{Materials and methods}

\subsection{Animals, sampling and body weights (growth performance)}

The blood samples were obtained from five sheep breeds viz; Rahmani ( $n=45 ; 20 \hat{\jmath}$, $25 \bigcirc)$, Barki ( $n=45 ; 19 \widehat{\jmath}, 26 \uparrow)$, Rahmani X Barki cross $(n=123 ; 54 \hat{\jmath}, 69 \uparrow)$, Awassi/Awassi X Suffolk cross $(n=38 ; 17 \hat{\jmath}, 21 q)$, and Ossimi $(n=35 ; 16 \lambda, 19+)$. The studied sheep breeds were originally from three geographical regions in Egypt as follows; Alexandria city (GPS: 31.206208 , 29.919704), Sakha (GPS: 31.087032, 30.948859), and Matrouh governorate (GPS: 31.336924 , 27.205762), but raised in north Egypt, Alexandria city "experimental station" (GPS: 31.206208, 29.919704) which they were kept under a semi-intensive system. Additionally, data on the body weight of both sheep sexes were collected concurrently at different three stages of age; at birth, weaning and six-month.

\subsection{DNA isolation and amplification}

Genomic DNAs were extracted from sheep blood samples with QIAGEN kit (Hilden, Germany). The isolated DNA was separated using Gel electrophoresis system (Biometra, USA) on 0.8-1.2\% agarose (B.Shop, Germany) in 0.5 X TBE buffer (Sambrook and Fritsch, 1997) and about $0.5 \mu \mathrm{g} / \mathrm{ml}$ ethidium bromide " $\mathrm{C}_{21} \mathrm{H}_{20} \mathrm{BrN}_{3}$ " (Sigma, Germany). The electrophoresis run was 
performed utilizing Gel electrophoresis system and visualized using the Gel documentation system (Alpha-chem. Imager, USA).

The specificities of the PCR primers targeting IGFBP-3 and GH genes were previously tested by Kumar et al., (2002) and Yousefi et al., (2013) respectively (Table 1). The amplification was performed using (S. Green Supermix, Germany), ten p.mol of each primer and 80-90 ng of genomic DNA processed under the amplification conditions as shown in (Table 2). The amplification was carried out utilizing a Thermo-cycler (Gene Amp 6700, Bio-system, USA).

Table 1. The listing primer and sequence $\left(5^{\prime} \rightarrow 3^{\prime}\right)$ of IGFBP-3, and GH genes.

\begin{tabular}{ccc}
\hline Locus & Method & \multicolumn{1}{c}{ Primer sequence (5' $\left.\rightarrow \mathbf{3}^{\prime}\right)$} \\
\hline \multirow{3}{*}{ IGFBP-3 } & RFLP \& & F: 5'-CCAAGCGTGAGACAGAATAC -3' \\
& DNA & R: 5'-AGGAGGGATAGGAGCAAGAT-3' \\
\cline { 3 - 3 } GH & Sequencing & F: 5'-GAAACCTCCTTCCTCGCCC-3' \\
& DNA & R: 5'-CCAGGGTCTAGGAAGGCACA-3' \\
& Sequencing & \\
\hline
\end{tabular}

Table 2. Cycles conditions of PCR

\begin{tabular}{cccccccccc}
\hline Gene & \multicolumn{2}{c}{ Denaturation } & \multicolumn{2}{c}{ Annealing } & Extension & \multicolumn{2}{c}{$\begin{array}{c}\text { Final } \\
\text { extension }\end{array}$} & $\begin{array}{c}\text { Number of } \\
\text { cycles }\end{array}$ \\
\hline \multirow{2}{*}{ IGFBP-3 } & ${ }^{\circ} \mathbf{C}$ & Sec & ${ }^{\circ} \mathbf{C}$ & Sec & ${ }^{\circ} \mathbf{C}$ & Sec & ${ }^{\circ} \mathbf{C}$ & Sec & N \\
\cline { 2 - 10 } & 94 & 300 & 54 & 30 & 72 & 60 & 72 & 300 & 30 \\
\hline \multirow{2}{*}{ GH } & ${ }^{\circ} \mathbf{C}$ & Sec & ${ }^{\circ} \mathbf{C}$ & Sec & ${ }^{\circ} \mathbf{C}$ & Sec & ${ }^{\circ} \mathbf{C}$ & Sec & N \\
\cline { 2 - 9 } & 94 & 300 & $56 / 58$ & 30 & 72 & 45 & 72 & 120 & 35 \\
\hline
\end{tabular}

\subsection{Restriction Fragment Length Polymorphism (RFLP)}

The RFLP method was utilized to detect the differences in genotypes among the studied sheep breeds, using the PCR of the IGFBP-3 gene. The IGFBP-3 gene products from PCR were digested with the HaeIII restriction enzyme (Bio-search Technologies, USA). The PCR-RFLP reaction volume was $25 \mu \mathrm{l}$, consisted of $2 \mu \mathrm{l} 10 \mathrm{X}$ digestion buffer, $1 \mu \mathrm{l}$ restriction enzyme, $12 \mu \mathrm{l}$ $\mathrm{H}_{2} \mathrm{O}$, in addition to $10 \mu \mathrm{PCR}$ product. All reactions were incubated at $37^{\circ} \mathrm{C}$ with $\mathrm{HaeIII}$ for 16 h. $20 \mu \mathrm{l}$ of each reaction were separated using the Gel electrophoresis system on 2.5-3\% agarose gel and visualized by gel documentation system. Genotypes were detected by inspecting RFLP patterns.

\subsection{Nucleotide sequence analysis}

The DNA sequence analysis was achieved on both strands for GH and IGFBP-3 genes by the lab service of Functional Foods \& Nutrition (Alexandria, Egypt) with an (ABI Prism 3100 
apparatus, USA). Database similarity discoveries were carried out with the blast network service /BLAST at (NCBI) (http://www.ncbi.nlm.nih.gov). The sequences were analysed utilizing Finch T.V 1.01, Blast 2.0, and MEGA $6 \mathrm{~V} .4$ software to detect SNPs among the different sequences. The sequences of GH gene for studied animals were deposited in GenBank under Accession Numbers; KP893631.1, KP893632.1, KP893634.1, KP893633.1, and KP893635.1 for Rahmani, Barki, Rahmani X Barki cross, Awassi/Awassi X Suffolk cross, and Ossimi, respectively, as for IGFBP-3, the sequence was deposited in GenBank under Accession Number; (Accession no. MG738671.1) for studied breeds. Analysis of translated protein of GH gene sequences for tested sheep breeds was generated using ExPASy program (http://web.expasy.org/translate).

\subsection{Statistical Analysis}

Data of birth, weaning and six-month weights of the breeds under study were collected and investigated for normality by the Shapiro-Wilk test (SAS, 2009), and results refereed that all data were distributed normally [Shapiro-Wilk test $(\mathbf{W}) \geq \mathbf{0 . 9 0}$ ]. Also, the GLM procedure of SAS was used to determine the effects of breed on weights according to the following model:

$$
\mathbf{Y}_{\mathrm{ij}}=\boldsymbol{\mu}+\mathbf{B}_{\mathbf{i}}+\mathbf{e}_{\mathbf{i j}}
$$

Where: $\mathbf{Y}_{\mathbf{i j}}=$ animal weight trait, $\boldsymbol{\mu}=$ the overall mean, $\mathbf{B}_{\mathbf{i}}=$ the fixed effect of $\mathbf{i}^{\mathbf{t h}}$ breed, and $\mathrm{e}_{\mathbf{i j}}=$ the residual error. Significant differences between means within each weight were tested using least significant difference $\left(\mathrm{LSD}_{0.05}\right)$.

\section{Results and Discussion}

\subsection{Amplification, purification, manipulation, and digestion}

This investigation concerns mainly the polymorphism among tested sheep groups for IGFBP-3 and GH genes. It also spotlights the relationship between differentiation of these genes and their association with weights at birth, weaning and six-month. PCR amplification for the tested sheep breeds produced an amplified $654 \mathrm{bp}$ fragment for IGFBP-3 gene (Fig. 1a), and 365 bp for GH gene (Fig. 1b).

\subsection{Insulin-like Growth Factor Binding Protein-3 (IGFBP-3) gene}

The PCR products of IGFBP-3 gene obtained from experimental sheep were digested with HaeIII. Digestion profile revealed one pattern of eight DNA fragments sized 201, 201, 87, 67, 57, 18, 16 and 7 bp for all sheep (Fig. 2a). These results mean that; no polymorphism has been detected within IGFBP-3 gene among the studied sheep breeds. Also, the nucleotide sequencing of the amplified fragment of IGFBP-3 gene of studied sheep breeds with NCBI GenBank (Accession no. MG738671.1) confirmed the same result (Fig. 2b). 


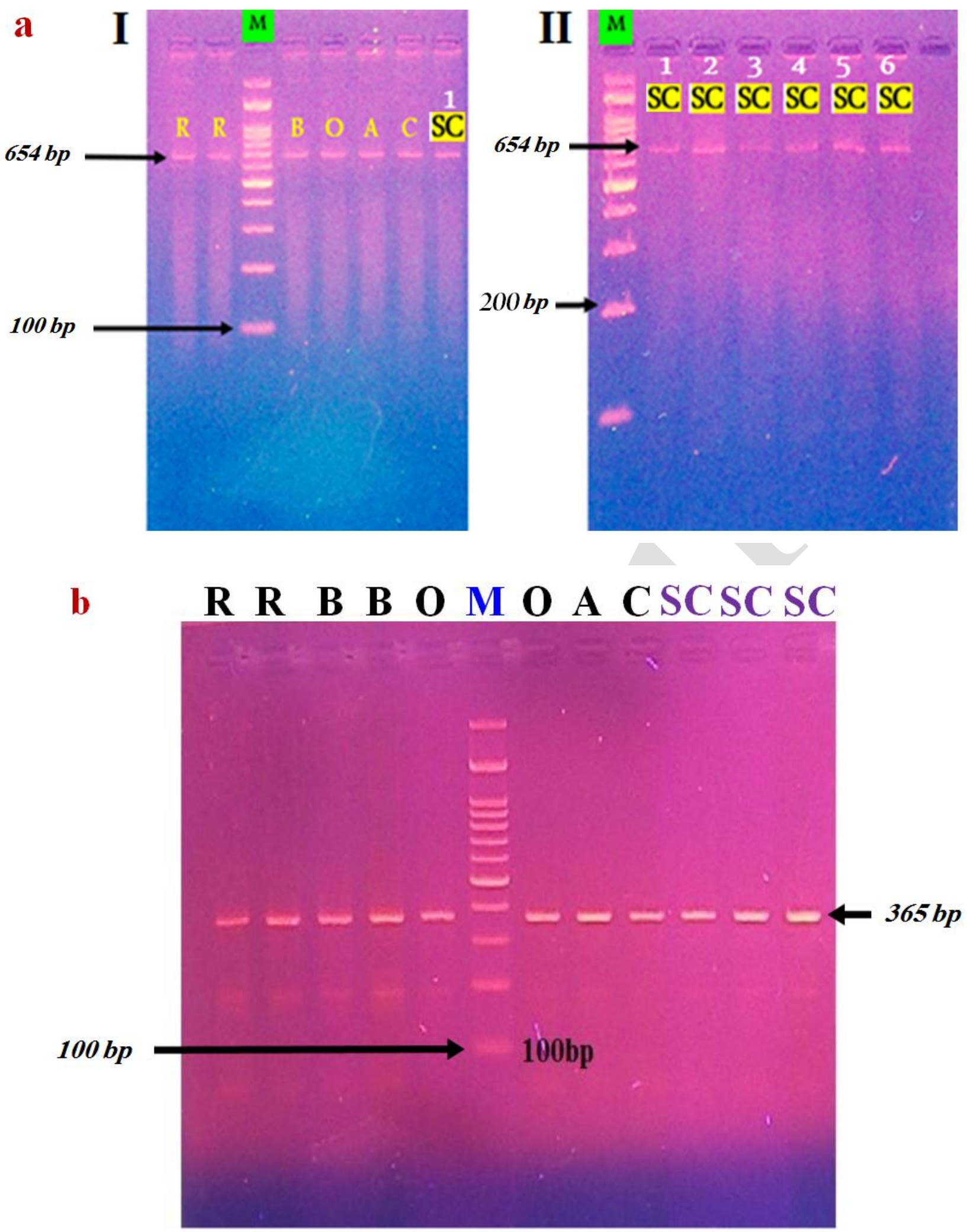

Fig. 1. (a) I-Purified PCR product of IGFBP-3 gene from Rahmani (R), Barki (B), Ossimi (O), Rahmani X Barki cross (C), and Awassi (A)/Awassi X Suffolk cross (SC), M;100 bp DNA ladder and II- Purification of IGFBP-3 gene (654bp) from Awassi X Suffolk cross (SC), M; DNA ladder with 100 bp. (b) PCR amplification of GH gene from genomic DNA of Rahmani (R), Barki (B), Ossimi (O), Awassi (A), Rahmani X Barki cross (C), and Awassi X Suffolk cross (SC), M;100 bp DNA ladder. 


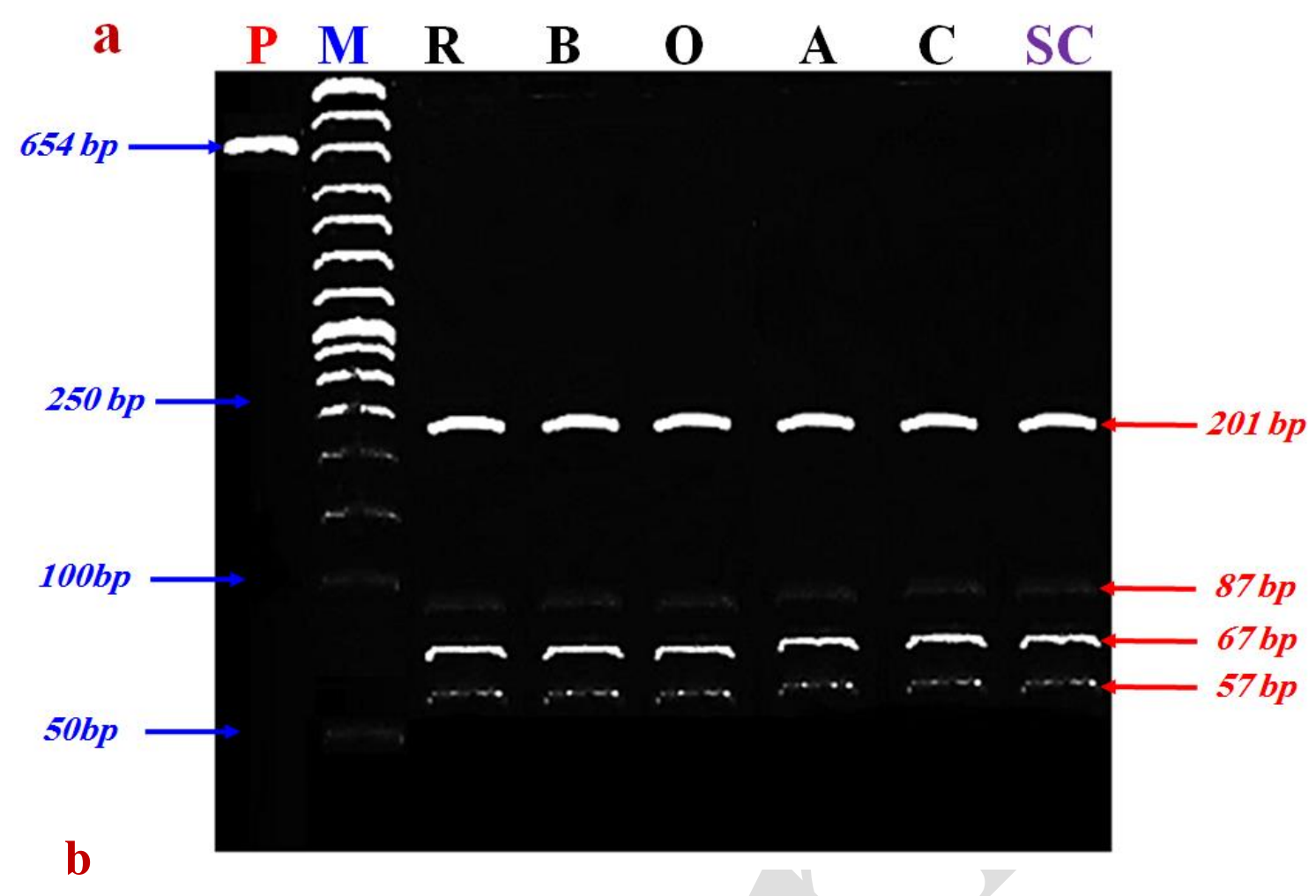

CCAAGCGTGAGACAGAATCCGTAAGAGCTTTTCCTCTTGTTGTTGTGGGGGTGGG^ CCCACCTGGGCTGGGTATCCAGAGATCACAGGGTCACCATTGACTCAAGAGCCCAG CAGTTACTCCAAACCTGGTGCTGATGCACCAAGCAGCTGTGAGCCCCTCCTACAGA AGGGATATTGACCCTCCCCTGTGGCAGAGATCCCTTGAGAATCAGGGTACTGCTCT TCAGACCTCTGCTGGGCAGAGCAGTGTTCTCCCAAAGCTGG^CCTCTTTTTGTTCAC TTGG^ ${ }^{\wedge}$ CCTCTGAGTGG^CCTGGCCTGTGTGCCCCTGTCCCAGTTCTATGGCTTGCCCT GGGGAATCATGAGAGAGACAGGGGGCTGTGGCTGGCATCTGCATGGGAACGGTGA CAACTAAATCAGACAAAAGATACTCGAGGAGCACATGGTCAGTTCCCTGGGTGTTA TGGGGTTTTATCAAACACAGAGTTCCCAGGTAACCCGTCCCTCCTCCCCGGGGG^CC AGGTTGCCGGGAAATGGAGGACACACTGAACGG^CCTCAAGTTCCTGAACACACTC AGCCCCAGGG^CCATCCACATTCCCAACTGTGACAAGAAGGGCTTACTCGAGGAGG CACCTAACAACGACCTCATCAATTCTCGCTCCTATCGG

Fig. 2. (a) The PCR products of the IGFBP-3 gene from genomic DNA of tested sheep breeds digested by HaeIII; Rahmani (R), Barki (B), Ossimi (O), Rahmani X Barki cross (C) and Awassi (A)/Awassi X Suffolk cross (SC). M, 50 bp DNA ladder, P; PCR product for IGFBP-3. The digestion with HaeIII revealing a single pattern only for 8 DNA fragments sized 201, 201, 87, 67, 57, 18, 16 and $7 \mathrm{bp}$ for IGFBP-3 gene. The restriction fragments with sizes; 18, 16 and $7 \mathrm{bp}$ were not seen on the gel. (b) A 654 bp sequence of IGFBP-3 gene of studied sheep breeds (NCBI accession no. MG738671.1). 
On the other side, genetic differentiation of this gene in livestock species including sheep was under investigation (Liu et al., 2012; Saleh et al., 2019; Sankhyan et al., 2019; Sarmah et al., 2019; Splaine et al., 2019). Li et al., (2008) reported three genotypes of IGFBP-3 among seven populations of goats with significantly high association with weaning weight, body length, rib eye area, heart girth, and body length. Also, Choudhary, (2004) identified three genotypes of IGFBP-3 in exotic Holstein Friesian and Jersey cattle. The polymorphism with respect to this gene in cattle was due to C/A (GGCC to GGAC) transition in intron number 2 of this gene at 299 position bases at the sequence, which alters the HaeIII restriction site. (Saleh et al., 2019) confirmed that the digestion of IGFBP-3/HaeIII yielded three genotypes for cattle. Sharma et al., (2014) reported that 6 SNPs out of 8 mutations in Indian goats were found to be synonymous in IGFBP-3 but were found to be nonsynonymous in nine goat breeds. This was also in accordance with the findings reported on Chinese goat (Lan et al., 2007a), which indicate that caprine IGFBP3 gene may have more functionality. Amino acid sequence variation in caprine IGFBP-3 gene may also be functional, so that affected the expression of the enzyme activity of the gene (Sharma et al., 2014).

In the current study, there was no polymorphism found among studied sheep breeds for IGFBP-3 gene. This agrees with the previous study (Saleh et al., 2019) that the digestion of IGFBP-3 with HaeIII yielded one RFLP pattern for goats, and for buffalo, one genotype (AA) was found when HaeIII and TaqI restriction enzymes were used separately, while three genotypes were found for cattle. Also, the current results agree with those of Ali et al., (2009) who reported that the RFLP pattern for IGFBP-3/HaeIII obtained for some sheep breeds yielded one pattern of five fragments sized 201, 201, 87, 67, and 57 bp. Also, with Kumar et al., (2006) who studied the genetic diversity among Indian sheep breeds, Mandya, Marwari, Madras, Banur, and Red Muzaffarnagari for the sequence of IGFBP-3 gene digested by HaeIII and reported that the digestion profile revealed only one pattern with 8 DNA fragments for all sheep breeds and no polymorphism was detected. Also, these results were in accordance with those reported on six breeds of buffalo. Nevertheless, the fragments sizes were various which indicated a lack of polymorphism detected for the six buffalo breeds with respect to IGFBP-3 gene.

In contrary, Rasouli et al., (2017) discovered that three genotypes (CC, TC, and TT) and a mutation of IGFBP-3 gene "Exon 2/ 316 bp" at position 58, besides three genotypes for IGF-I gene "5' Flanking region/ 249bp" (GG, GA, and AA) and a mutation at position 1617. Their discoveries indicated that different genotypes of these genes had an effect on birth, and six-month weights, but the interactions among different genotypes of both genes were significant for weaning weight, and ADG from birth to weaning. Also, Li et al., (2008) investigated 7 different populations of goats by PCR-RFLP. They found three genotypes (AA, AG, and GG) in the IGFBP-3 gene. The correlation between different genotypes and weaning weight, $10^{\text {th }}$ month body length, rib eye area, $10^{\text {th }}$ heart girth, and $12^{\text {th }}$ month body length were significant $(P<0.05)$ and the association was significant for $3^{\text {rd }}$ heart girth and body length at $3^{\text {rd }}$ month $(P<0.01)$. The genetic effect of AG genotype was significantly higher than GG genotype for weaning weight and rib-eye area $(P<0.05)$ whilst, the above five physical measure traits were $(P<0.01)$. Additionally, according to Lan et al., (2007b) there are associations between mutations in IGFBP3 and weight traits at birth, 6 months, and 12 months and twining rate in Inner Mongolia White 
Cashmere, Xinong Sannen, Laoshan, Guanzhong, Guizhou White, Shaanan White, and Leizhou breeds. They found two SNPs; $A>G$ (position: 78 of intron 2), and G>A (position: 217 of intron $2)$ of IGFBP-3 gene are possibly associated with production traits $(P>0.05)$. Also, two mutations in this gene revealed a significant association with twinning rate $(P<0.05)$; $\mathrm{C}>\mathrm{T}$ (position: 58 of exon 2/ Proline to Serine), and $C>G$ (position: 67 of exon 2 / Arginine to Glutamic).

Worth mentioning, in a study to detect the novel SNPs of IGFBP-3 and their associations with litter size (LS) and weight traits in goat, the genotype was significantly associated with LS $(\mathrm{P}<0.05)$. However, no significant correlation of SNP with weight traits were detected at $(\mathrm{P}>0.05)$. While, two mutations in IGFBP3 showed a significant association with fertility traits (Lan et al., 2007a). Association investigations are, thence, warranted to evaluate the necessary role of these SNPs in production traits for sheep populations (Choudhary, 2004).

\subsection{Growth hormone $(\mathrm{GH})$ gene}

\subsubsection{Nucleotide sequence and amino acid sequence comparisons for GH gene}

Nucleotide sequencing of the amplified fragment of GH gene of Rahmani, Barki, Rahmani X Barki cross, Awassi/Awassi X Suffolk cross, and Ossimi were submitted to the GenBank "NCBI" under accession numbers: KP893631.1, KP893632.1, KP893634.1, KP893633.1 and KP893635.1, respectively (Fig. 3). Sequencing of the amplified GH gene fragments of the tested sheep breeds was generated by ExPASy program and the nucleotide analysis and percent distances of GH gene fragments for sheep breeds (Fig.4 and Table 3) along with comparisons of amino acids were generated by MEGA 6 V.4 (http://en.biosoft.net/tree/MEGA .html) (Fig. 5).

Table 3. Nucleotide sequence distances, percent similarity (above diagonal), percent distance (below diagonal); of GH gene of tested sheep breeds.

\begin{tabular}{cccccc}
\hline Breeds & Rahmani & Barki & RXB* & Awassi/SC** & Ossimi \\
\hline Rahmani & - & 0.98 & 0.98 & 0.98 & 0.99 \\
\hline Barki & 0.0341 & - & 0.99 & 0.98 & 0.97 \\
\hline RXB* & 0.0468 & 0.0149 & - & 0.97 & 0.97 \\
\hline Awassi/SC ** & 0.0307 & 0.0211 & 0.0303 & - & 0.97 \\
\hline Ossimi & 0.0339 & 0.0398 & 0.0367 & 0.0465 & - \\
\hline
\end{tabular}

*RXB; Rahmani X Barki cross, **SC; Awassi X Suffolk cross 


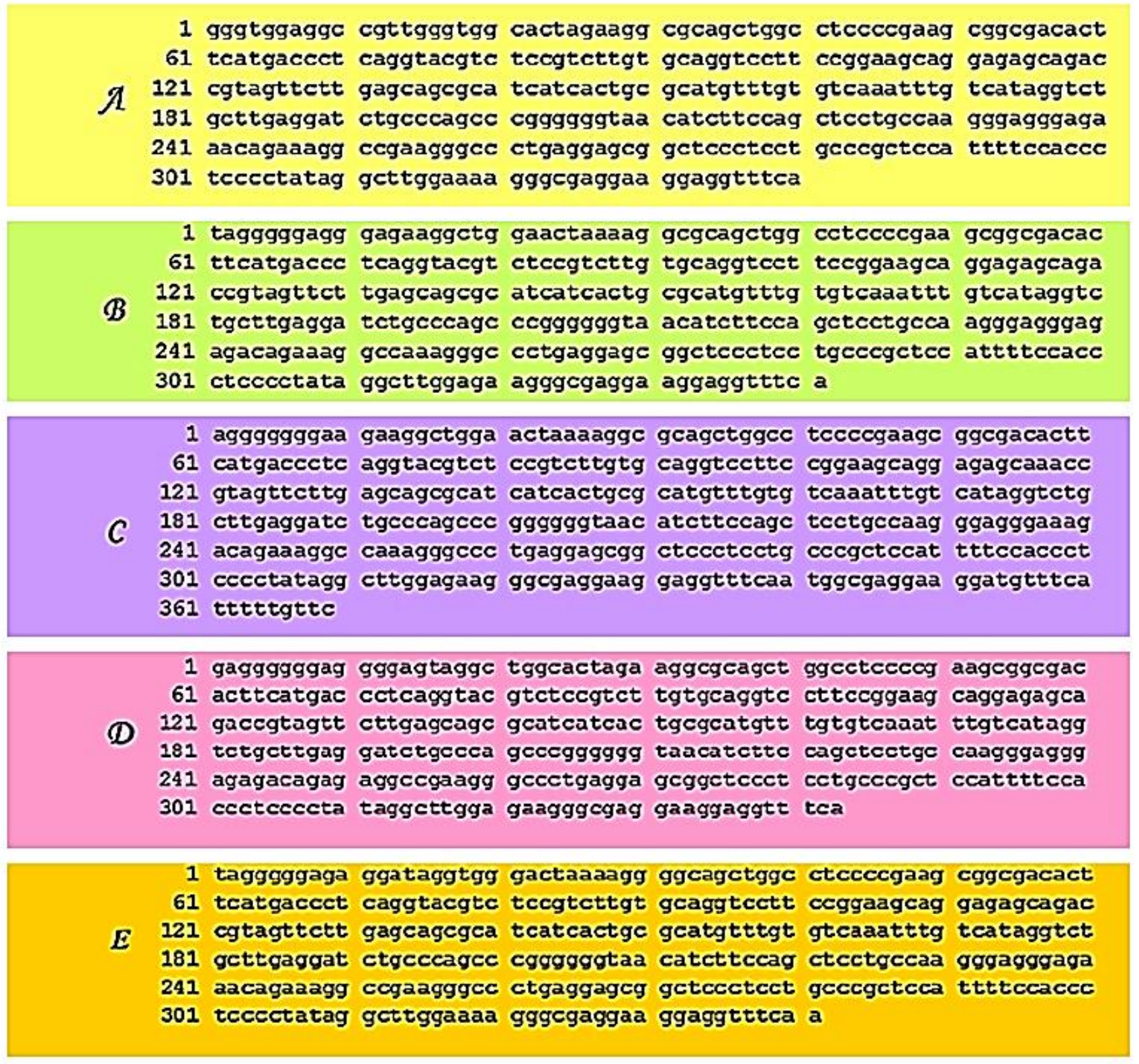

Fig. 3. (A) A 365 bp sequence of GH gene of Rahmani breed (NCBI accession no. KP893631.1), (B) A 365 bp sequence of GH gene of Barki breed (NCBI accession no. KP893632.1), (C) A 365bp sequence of GH gene of Rahmani X Barki crossbreed (NCBI accession no. KP893634.1), (D) A 365 bp sequence of GH gene of Awassi/Awassi X Suffolk cross (NCBI accession no. KP893633.1), (E) A 365 bp sequence of GH gene of Ossimi breed (NCBI accession no. KP893635.1). 


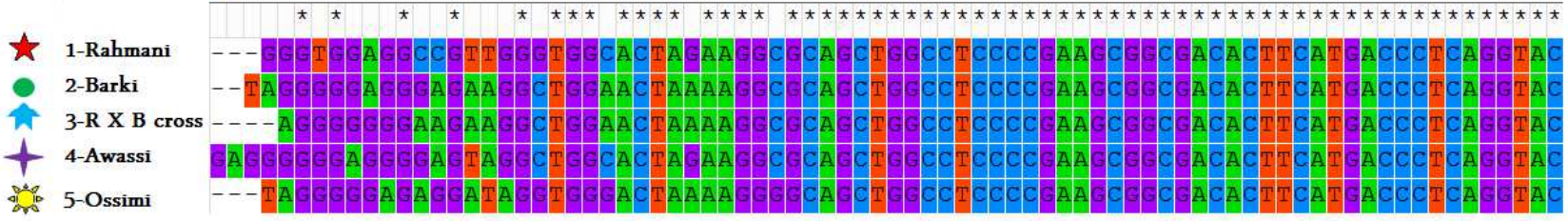

81

160

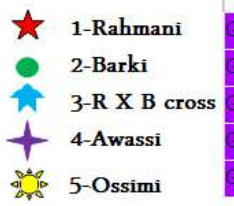

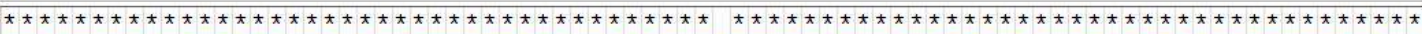

3TCTCCGTCTTGTCAGGTCCTTCCGGAAGCAGGAGAGCAGACCGTAGTTCTTGAGCAGCGCATCATCACTGCGCATGTT STCTCCGTCTT GT GAGGTCCTICCGGAAGCAGGAGAGCAGACCGTAGTTCTT AAGCAGCGCATCATCACTGCGCATGTT

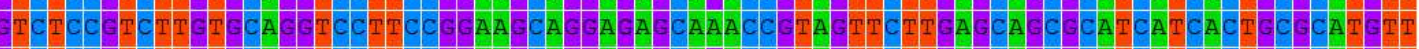

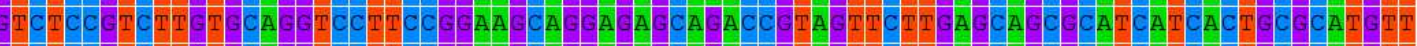

Dip

161

240

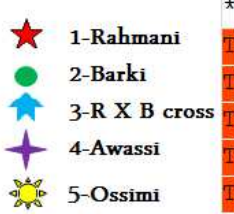

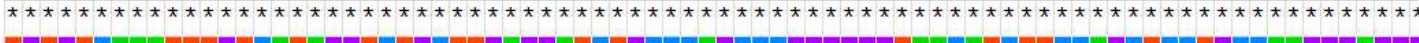

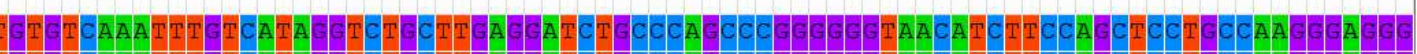
TGT GTCAAATT TICATA GTCTGCTIGAGGATCT GCCAGCCCGGGGGGAACATCTTCCAGCTCCTGCCAAGGGAGGG TGT GTCAAATT GTCATAGGTCTGCTTGAGGATCTGCCCAGCCCGGGGGGAACATCTTCCAGCTCCTGCCAAGGGAGG TGT GTCAAATT GTCATAGGTCTGCTT GAGGATCT GCCCAGCCCGGGGGGIAACATCTTCCA GCTCCTGCCAAGGGAGGG

of: 5-Ossimi

241

320

$\begin{array}{ll}\text { 1 } & \text { 1-Rahmani } \\ \text { 2-Barki } & \text { 3-R X B cross } \\ \text { A } & \text { 4-Awassi } \\ \text { A } & \text { A-Ossimi }\end{array}$

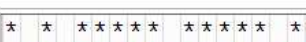

A GAAACA GAAAGGCCGAAGGGCCCTGAGGAGCGCTCCCTCCTCCCCGCTCCATTTTCCACCCTCCCCTATAGGCTTGGA

A GA GACA GAAAGGCCAAAGGGCCTGAGGA GCGGTCCCTCCTGCCCGCTCCATTTTCCACCCTCCCCTATAGGCTTGGA

AAA GACA GAAA G CCAAA GGCCCT GA GGA GCGGCTCCCTCCT GCCCGCTCCATTTTCCACCCTCCCCTATA GGCTTGGA

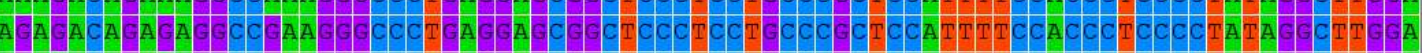

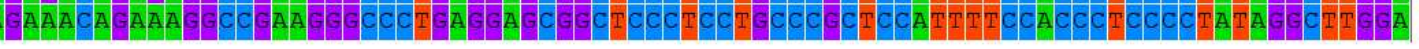

321

375

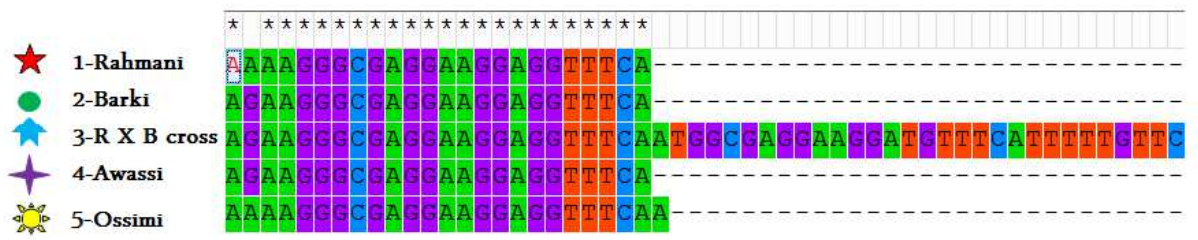

Fig. 4. Nucleotide sequence comparison of amplified GH gene of tested sheep breeds.

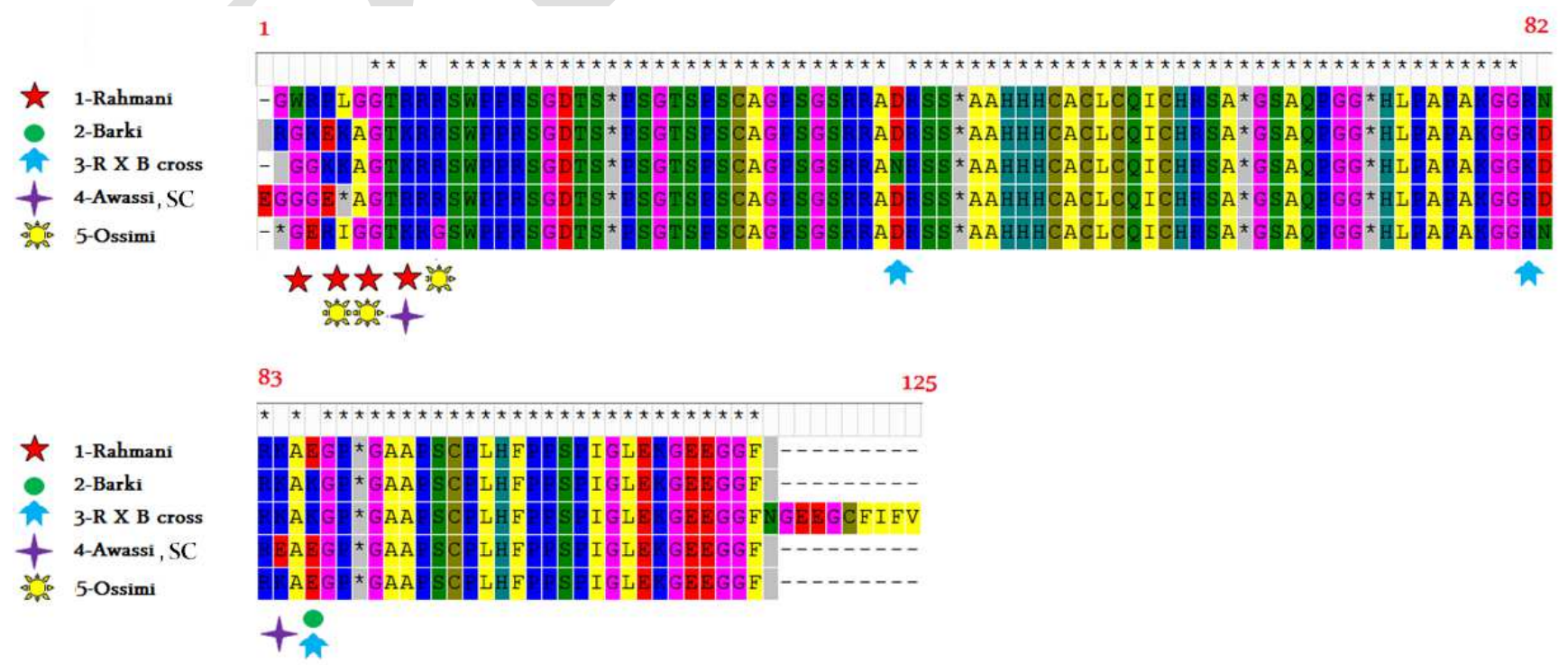

Fig. 5. Comparative analysis of amino acid sequences of GH gene of tested sheep breeds. 
The protein sequence of Rahmani breed was different from that of other breeds in four amino acids are Tryptophan, Leucine, Glycine and Arginine instead of Glycine, Lysine, Alanine and Lysine in other breeds, while in Rahmani X Barki cross the protein sequence was different from that of other breeds in three amino acids; Asparagine, Lysine and Lysine, in place of Aspartic, Arginine and Glutamic. Also, Ossimi breed protein sequence was different from that of other breeds sequence in three amino acids are (Arginine), (Glycine), and (Glycine) instead of (Glutamic or Lysine or Proline), (Alanine), and (Arginin). Hence, there was approximately (96.25 $\%$ ) similarity in the amino sequences among tested sheep breed (Table 4).

Table 4. Dissimilarity between amino acids in protein sequences in tested sheep breeds.

\begin{tabular}{|c|c|c|c|c|}
\hline No. & 1 & 2 & 3 & 4 \\
\hline 1- Rahmani & $\begin{array}{c}(\mathbf{W}) \\
\text { Tryptophan }\end{array}$ & $\begin{array}{c}(\mathbf{L}) \\
\text { Leucine }\end{array}$ & $\begin{array}{c}\text { (G) } \\
\text { Glycine }\end{array}$ & $\begin{array}{c}(\mathbf{R}) \\
\text { Arginine }\end{array}$ \\
\hline $\mathbf{O} *$ & $\begin{array}{c}\mathbf{G}) \\
\text { Glycine }\end{array}$ & $\begin{array}{c}(\mathbf{K}) \\
\text { Lysine }\end{array}$ & $\begin{array}{c}\text { A } \\
\text { Alanine }\end{array}$ & $\begin{array}{c}\mathbf{K}) \\
\text { Lysine }\end{array}$ \\
\hline 2- Barki & $\begin{array}{c}(\mathbf{K}) \\
\text { Lysine }\end{array}$ & & & \\
\hline O* & $\begin{array}{c}\mathbf{E}) \\
\text { Glutamic } \\
\end{array}$ & & & \\
\hline 3- RXB** & $\begin{array}{c}\mathbf{( N )} \\
\text { Asparagine }\end{array}$ & $\begin{array}{c}(\mathbf{K}) \\
\text { Lysine }\end{array}$ & $\begin{array}{c}(\mathbf{K}) \\
\text { Lysine }\end{array}$ & \\
\hline O* & $\begin{array}{c}\text { (D) } \\
\text { Aspartic }\end{array}$ & $\begin{array}{c}\text { (R) } \\
\text { Arginine }\end{array}$ & $\begin{array}{c}\mathbf{( E )} \\
\text { Glutamic }\end{array}$ & \\
\hline 4- Awassi/SC**** & $\begin{array}{c}(\mathbf{R}) \\
\text { Arginine }\end{array}$ & $\begin{array}{c}(\mathbf{E}) \\
\text { Glutamic }\end{array}$ & & \\
\hline O* & $\begin{array}{c}\mathbf{K}) \\
\text { Lysine } \\
\end{array}$ & $\begin{array}{c}\mathbf{K}) \\
\text { Lysine }\end{array}$ & & \\
\hline 5- Ossimi & $\begin{array}{c}(\mathbf{R}) \\
\text { Arginine }\end{array}$ & $\begin{array}{c}(\mathbf{G}) \\
\text { Glycine }\end{array}$ & $\begin{array}{c}(\mathbf{G}) \\
\text { Glycine }\end{array}$ & \\
\hline $\mathbf{O}^{*}$ & $\begin{array}{c}\text { (E, K, P) } \\
\text { Glutamic, Lysine, } \\
\text { Proline }\end{array}$ & $\begin{array}{c}\text { (A) } \\
\text { Alanine }\end{array}$ & $\begin{array}{c}\text { (R) } \\
\text { Arginine }\end{array}$ & \\
\hline
\end{tabular}

$* \mathbf{O}=$ Other studied sheep breeds, $* * \mathbf{R X B}=$ Rahmani X Barki cross, $* *$ SC $=$ Awassi X Suffolk cross

Growth performance, body weight and body size are important indicators of body growth and some other breeding traits as well (Okoro et al., 2010). Mahrous et al., (2018) studied the polymorphism of GH gene for the three loci; GH-1, -2, and -6 in three goat breeds; Damascus, Barki, and Zaraibi, utilizing RFLP and DNA analyses and confirmed the absence AA of genotype, which all animals had genotypes BB or AB. Worth mentioning, An et al., (2011) when investigated the polymorphisms of GH gene in Boer (BG) and Xinong Saanen (SG) goats found two alleles (A and $\mathrm{B}$ ) and three genotypes (AA, AB and BB) using SSCP. In addition, a SNP at A73C, was discovered by DNA sequencing. Polymorphisms of this gene was shown to be 
associated with growth traits in BG breed and AA genotype was associated with superior growth of animals up to 3 months of age.

\subsection{The weight at birth, weaning and six-month}

Table 5 shows birth, weaning, and six months weights for Barki, Rahmani, Rahmani X Barki crosses, Awassi/Suffolk crosses and Ossimi. Birth weight of Rahmani X Barki crossbred lambs was the highest $(\mathrm{P}<0.05)$ followed by Barki which was higher $(\mathrm{P}<0.05)$ than Rahmani, Awassi/ Suffolk crosses and Ossimi lambs. However, Rahmani is known to have the highest twinning rates (Saleh et al., 2020) and, therefore, the highest litter birth weight among all breeds (Marai et al., 2009). Awassi and crossbred lambs growth from birth to weaning were the highest which caused their weaning weights to be significantly higher than that of other breeds. Also, Rahmani lambs achieved relatively high growth rate at the same period which permitted them to catch up with Barki lambs, therefore no significant differences were found between the two breeds but both had higher weaning weights $(\mathrm{P}<0.05)$ than Ossimi lambs. At six months of age Awassi/ Suffolk crosses lambs scored the highest weight $(\mathrm{P}<0.05)$ indicating good breed mothering ability from birth to weaning and better-growing ability thereafter. Rahmani X Barki cross maintained high weight superiority throughout the period from birth to six months of age above their purebred parents and Ossimi lambs. Rahmani and Barki lambs went side by side for weaning and six-month weights, regardless of the lower birth weight of Rahmani, and both breeds had heavier six-month weight than Ossimi.

Table 5. Mean, standard deviation (SD), coefficient of variation (CV) and range for birth, weaning and six-month weights of sheep breeds under study.

\section{Weights (kg)}

\begin{tabular}{lccccccccc}
\cline { 3 - 9 } Breeds & \multicolumn{3}{c}{ Birth } & \multicolumn{3}{c}{ Weaning } & \multicolumn{3}{c}{ Six month } \\
\cline { 2 - 10 } & Mean & S.D & C.V & Mean & S.D & C.V & Mean & S.D & C.V \\
\hline Barki & $4.10^{\mathrm{b}}$ & 0.38 & 9.32 & $19.90^{\mathrm{b}}$ & 2.57 & 12.92 & $24.05^{\mathrm{c}}$ & 3.52 & 14.65 \\
\hline Rahmani & $3.77^{\mathrm{c}}$ & 0.48 & 12.66 & $19.89^{\mathrm{b}}$ & 2.71 & 13.62 & $24.00^{\mathrm{c}}$ & 3.58 & 14.93 \\
\hline RXB $^{*}$ & $4.40^{\mathrm{a}}$ & 0.53 & 12.06 & $22.17^{\mathrm{a}}$ & 3.16 & 14.25 & $27.30^{\mathrm{b}}$ & 3.71 & 13.58 \\
\hline Awassi/SC** & $3.50^{\mathrm{c}}$ & 0.25 & 7.15 & $23.23^{\mathrm{a}}$ & 1.74 & 7.51 & $31.64^{\mathrm{a}}$ & 2.19 & 6.92 \\
\hline Ossimi & $3.69^{\mathrm{c}}$ & 0.20 & 5.45 & $17.00^{\mathrm{c}}$ & 0.96 & 5.65 & $21.70^{\mathrm{d}}$ & 1.29 & 5.97 \\
\hline Overall & - & 0.41 & 10.40 & - & 2.5 & 11.96 & - & 3.25 & 12.16 \\
\hline
\end{tabular}

$* \mathbf{R X B}=$ Rahmani X Barki cross, ${ }^{* *} \mathbf{S C}=$ Awassi X Suffolk cross, ${ }^{\text {a-c }}$ Means with different letters in the same column within the same factor are significantly different. 


\subsection{The relationship between growth performance and the prevalence of GH gene genotypes}

In the current study, the differentiated amino acid sequences of GH in different studied sheep breeds were accompanied with variation in body weights and growth performance which may suggest a direct influence of $\mathrm{GH}$ protein sequence on the growth pattern of sheep. Additionally, Yousefi et al., (2013) reported that; $\mathrm{o}^{\mathrm{GH}}$ gene has been used as a candidate gene for growth rate in many livestock species.

This is in agreement with Malewa et al., (2014) who reported apparent effects of the genotypic polymorphism for GH gene on growth rate and weaning weight, also, was in agreement with finds of Kumari et al., (2014) who investigated genetic polymorphisms of GH gene at loci A1575G and A781G in nine sheep breeds from different regions in India. Their results revealed that; genetic variation exists at A781G locus which paved a lane for investigation of QTL for growth traits in the tested breeds. Also, in the study of Gorlov et al., (2017), it was confirmed that polymorphism in GH gene was associated with growth traits in Salsk sheep "Russian Federation" and they discovered three genotypes $\mathrm{AA}, \mathrm{AB}$ and $\mathrm{BB}$, the $\mathrm{AB}$ was found to have great effects on weaning and 9 months, body weights, ADG, and slaughter, and carcass weights. Hua et al., (2009) confirmed that the polymorphism of GH gene was as a candidate gene for several growth traits in Boer goat bucks, where two SNPs were discovered for GH gene; A1575G " Leucine 147 " with two genotypes (CC, and CD), and A781G " Serine/Glycine ${ }^{35}$ " with other two genotypes (AA, and $\mathrm{AB}) . \mathrm{AB}$ genotype resulted in a significant increase in weaning weight $(\mathrm{P}=0.014)$ and chest girth at birth $(\mathrm{P}=0.03)$ comparing to AA genotype, while $\mathrm{CD}$ genotype contributed to weaning height $(\mathrm{P}=0.04)$ less than $\mathrm{CC}$ genotype. On the contrary, according to a genetic study on $\mathrm{GH}$ gene of Zel sheep breed, no significant effect $(\mathrm{P}>0.05)$ between yearling weights of different $\mathrm{GH}$ genotypes was found (Yousefi and Azari, 2012).

The variation between breeds with respect to body weights and growth rates at different stages of maturity under prevalence of different GH genotyping may reflect a relatedness between these differentiation and growth performance of sheep. This should strongly recommend the utilization of sheep GH gene in the primary steps of MAS program with deeper studies to follow, especially for IGFBP-3 where these genes are considered as candidates for controlling growth in sheep, also, they play a necessary role in the regulation of growth and development (Baldi, 1999; Saleh et al., 2019).

\section{Conclusions}

Improving sheep production is strongly based on animal genetics as most of the quantitative economic traits have polygenetic nature. Molecular tools provide valuable knowledge that could contribute to enriching the information about genes underlying economical traits. In view of the lack of enough investigations about the genetic polymorphisms of production genes in Egyptian sheep breeds, the aims of this work were to study the differentiation "polymorphisms" in IGFBP-3 and GH genes and their association with several growth traits. The important role of IGFBP-3 and GH genes in growth performance is well recognized, then their polymorphisms and interaction with the growth trait should be the subject of further research. According to the current 
study, the probable presence of an association between differentiation in genotypes of GH gene and growth performance also, weight at birth, weaning and six-month could be candidate markers in sheep breeding program for improvement of growth rates.

\section{Declarations}

\section{Funding}

This research did not receive any specific grant from funding agencies in the public, commercial, or not-for-profit sectors.

\section{Ethical approval}

The management of the experimental animals was in agreement with the welfare guidelines approved by the Animal and Fish Production Department, College of Agriculture, Alexandria University, Egypt (No. AFP7-AB2-1016). Also, all procedures and experimental protocols were in accordance with the Guide for the Care and Use of Agricultural Animals in Research and Teaching, Federation of Animal Science Societies (FASS, 2010) https://www.aaalac.org/about/Ag_Guide_ 3rd_ed.pdf.

\section{Authors' contributions}

The work presented here was carried out in collaboration between all authors. A.S, M.SH, N.D, and M.H defined the research theme. A.S, M.SH and E.H designed methods and experiments, A.S carried out the laboratory experiments, A.S, and M.SH organized the data, A.S, M.SH, and N.D interpreted the results and wrote the manuscript. A.S co-worked on associated data collection and their interpretation. All authors reviewed the manuscript. All authors read and approved the final manuscript.

\section{Acknowledgements}

The authors gratefully thank the working team of Functional Foods \& Nutrition Laboratory (FFNL), Dairy Science and Technology Department- Faculty of Agriculture (Alshatby) - Alexandria University, Alexandria, Egypt, which were really fruitful.

\section{Availability of data and material}

All data generated or analyzed during this study are included in this manuscript

\section{References}

Ali, B., El-Hanafy, A. and Salem, H., 2009. Genetic biodiversity studies on IGFBP-3 gene in Egyptian sheep breeds. Biotechnology in Animal Husbandry 25, 101-109.

An, X., Wang, L., Hou, J., Li, G., Song, Y., Wang, J., Yang, M., Cui, Y. and Cao, B., 2011. Novel polymorphisms of goat growth hormone and growth hormone receptor genes and their effects on growth traits. Molecular biology reports 38, 4037-4043. 
Baldi, A., 1999. Manipulation of milk production and quality by use of somatotropin in dairy ruminants other than cow. Domestic Animal Endocrinology 17, 131-137.

Bathaei, S.S. and Leroy, P.L., 1998. Genetic and phenotypic aspects of the growth curve characteristics in Mehraban Iranian fat-tailed sheep. Small Ruminant Research 29, 261 269.

Bauman, D.E., 1999. Bovine somatotropin and lactation: from basic science to commercial application. Domest Anim Endocrinol 17, 101-16.

Besnard, N., Pisselet, C., Monniaux, D., Locatelli, A., Benne, F., Gasser, F., Hatey, F. and Monget, P., 1996. Expression of messenger ribonucleic acids of insulin-like growth factor binding proteins-2,-4, and -5 in the ovine ovary: localization and changes during growth and atresia of antral follicles. Biology of reproduction 55, 1356-1367.

BK, C., Scaramuzzi, R. and Webb, R., 1995. Control of antral follicle development and selection in sheep and cattle. Journal of Reproduction and Fertility Supplement 49, 335-350.

Boyd, R.D. and Bauman, D.E., 1989. Mechanisms of action for somatotropin in growth, Animal growth regulation. Springer, pp. 257-293.

Breier, B., 1999. Regulation of protein and energy metabolism by the somatotropic axis. Domestic animal endocrinology 17, 209-218.

Choudhary, V., 2004. Molecular studies on leptin and insulin-like growth factor binding protein3 (IGFBP-3) genes in cattle. IVRI.

Currie, M., Bassett, N., Breier, B., Klempt, M., Min, S., Mackenzie, D., McCutcheon, S. and Gluckman, P., 1996. Differential effects of maternal ovine placental lactogen and growth hormone (GH) administration on GH receptor, insulin-like growth factor (IGF)-1 and IGF binding protein-3 gene expression in the pregnant and fetal sheep. Growth regulation 6 , 123-129.

Gluckman, P., Mueller, P., Kaplan, S., Rudolph, A. and Grumbach, M., 1979. Hormone ontogeny in the ovine fetus. I. Circulating growth hormone in mid and late gestation. Endocrinology 104, 162-168.

Gorlov, I.F., Kolosov, Y.A., Shirokova, N.V., Getmantseva, L.V., Slozhenkina, M.I., Mosolova, N.I., Bakoev, N.F., Leonova, M.A., Kolosov, A.Y. and Zlobina, E.Y., 2017. Association of the growth hormone gene polymorphism with growth traits in Salsk sheep breed. Small Ruminant Research 150, 11-14.

Guimarães, E.P., 2007. Marker-assisted selection: current status and future perspectives in crops, livestock, forestry and fish, Food \& Agriculture Org.

Hanrahan, J.P., Gregan, S.M., Mulsant, P., Mullen, M., Davis, G.H., Powell, R. and Galloway, S.M., 2004. Mutations in the genes for oocyte-derived growth factors GDF9 and BMP15 are associated with both increased ovulation rate and sterility in Cambridge and Belclare sheep (Ovis aries). Biology of reproduction 70, 900-909.

Herd, R., Archer, J. and Arthur, P., 2003. Reducing the cost of beef production through genetic improvement in residual feed intake: Opportunity and challenges to application. Journal of animal science 81, E9-E17.

Hua, G., Chen, S., Yu, J., Cai, K., Wu, C., Li, Q., Zhang, C., Liang, A., Han, L. and Geng, L., 2009. Polymorphism of the growth hormone gene and its association with growth traits in Boer goat bucks. Meat science 81, 391-395.

Juengel, J.L., 2018. How the quest to improve sheep reproduction provided insight into oocyte control of follicular development. Journal of the Royal Society of New Zealand 48, 143 163.

Khalid, M. and Haresign, W., 1996. Relationships between concentrations of ovarian steroids, insulin-like growth factor-1 and IGF-binding proteins during follicular development in the ewe. Animal Reproduction Science 41, 119-129. 
Kumar, P., Choudhary, V., Kumar, K.G., Bhattacharya, T., Bhushan, B., Sharma, A. and Mishra, A., 2006. Nucleotide sequencing and DNA polymorphism studies on IGFBP-3 gene in sheep and its comparison with cattle and buffalo. Small Ruminant Research 64, 285-292.

Kumar, P., Padma, B., Dhara, S., Kumar, K., Bhattacharya, T., Bhushan, B. and Sharma, A., 2002. PCR-RFLP studies on insulin-like growth factor binding protein-3 (IGFBP-3) gene in sheep, Proceedings of the 7th World Congress on Genetics Applied to Livestock Production, Montpellier, France. pp. 19-23.

Kumari, R., Kumar, R., Meena, A., Jyotsana, B., Prince, L. and Kumar, S., 2014. Genetic polymorphism of growth hormone gene in native sheep breeds of India. Indian Journal of Small Ruminants (The) 20, 15-18.

Lan, X., Pan, C., Chen, H., Lei, C., Liu, S., Zhang, Y., Min, L., Yu, J., Li, J. and Zhao, M., 2007a. The HaeIII and XspI PCR-RFLPs detecting polymorphisms at the goat IGFBP-3 locus. Small ruminant research 73, 283-286.

Lan, X., Pan, C., Chen, H., Zhao, M., Li, J., Yu, J., Zhang, C., Lei, C., Hua, L. and Yang, X., 2007b. The novel SNPs of the IGFBP3 gene and their associations with litter size and weight traits in goat (Brief report). Archives Animal Breeding 50, 223-224.

Lewis, R.M., 2018. Sheep: Breeding and Genetics, Encyclopedia of Animal Science-(TwoVolume Set). CRC Press, pp. 974-977.

Li, M.-y., Li, L., Min, L.-j. and Wang, J.-m., 2008. Genetic analysis of IGFBP-3 gene and its association with economic traits in goats. Chin. J. Anim. Vet. Sci 12.

Liu, H., Liu, C., Yang, G., Li, H., Dai, J., Cong, Y. and Li, X., 2012. DNA polymorphism of insulin-like growth factor-binding protein-3 gene and its association with cashmere traits in cashmere goats. Asian-Australasian journal of animal sciences 25, 1515.

Maciulla, J., Zhang, H. and DeNise, S., 1997. A novel polymorphism in the bovine insulin-like growth factor binding protein-3 (IGFBP3) gene. Animal genetics 28, 375-375.

Mahrous, K.F., Abdel-Aziem, S.H., Abdel-Hafez, M.A., Abdel-Mordy, M. and Rushdi, H.E., 2018. Polymorphism of growth hormone gene in three goat breeds in Egypt. Bulletin of the National Research Centre 42, 35.

Malewa, A., Hakim, L., Maylinda, S. and Husain, M., 2014. Growth hormone gene polymorphisms of Indonesia fat tailed sheep using PCR-RFLP and their relationship with growth traits. Livestock Research for Rural Development 26, 115.

Marai, I.F.M., Daader, A.H. and Bahgat, L.B., 2009. Performance traits of purebred Ossimi and Rahmani lambs and their crosses with Finnsheep born under two accelerated mating systems. Archives Animal Breeding 52, 497-511.

Mazerbourg, S. and Monget, P., 2018. Insulin-like growth factor binding proteins and IGFBP proteases: a dynamic system regulating the ovarian folliculogenesis. Frontiers in endocrinology 9, 134.

Newman, S., 1994. Quantitative-and molecular-genetic effects on animal well-being: adaptive mechanisms. Journal of animal science 72, 1641-1653.

Okoro, V., Ezeokeke, C., Ogundu, U. and Chukwudum, C., 2010. Phenotypic correlation of bodyweight and linear body measurement in Chinchilla rabbits (Orycotolagus cuniculus). Journal of Agricultural Biotechnology and Sustainable Development 2, 27-29.

Pereira, A.P., Alencar, M.M.d., Oliveira, H.N.d. and Regitano, L.C.d.A., 2005. Association of GH and IGF-1 polymorphisms with growth traits in a synthetic beef cattle breed. Genetics and Molecular Biology 28, 230-236.

Rachid, E.B., Boussad, B., Farid, M., Nassima, B.B.A., Amel, D., Fodil, A. and Faissal, G., 2019. Reproduction and Growth Performance of the Algerian Tazegzawt Sheep Breed. GENETICS AND BIODIVERSITY JOURNAL (GABJ) 3, 50-62.

Rasouli, S., Abdolmohammadi, A., Zebarjadi, A. and Mostafaei, A., 2017. Evaluation of polymorphism in IGF-I and IGFB-3 genes and their relationship tith twinning rate and growth traits in markhoz goats. Annals of Animal Science 17, 89-103. 
Saleh, A.A., 2016. Utilization of Molecular Markers to Detect some Genes and Mutations Affecting Economic Traits in Egyptian Sheep Breeds. 10.6084/m9.figshare.13026575 10.6084/m9.figshare.13026575.

Saleh, A.A., Hammoud, M.H., Dabour, N.A., Hafez, E.E. and Sharaby, M.A., 2020. BMPR-1B, BMP-15 and GDF-9 genes structure and their relationship with litter size in six sheep breeds reared in Egypt. BMC Research Notes 13, 215.

Saleh, A.A., Hammoud, M.H., Dabour, N.A., Hafez, E.E. and Sharaby, M.A, 2017. IGFBP-3 gene diversity among Egyptian sheep breeds. Alex. J. Agric. Sci. 6, 87-92.

Saleh, A.A., Hassanine, N.N., 2019a. Egyptian Sheep Breeds and genetic tools to improve. LAMBERT Academic Publishing. DOI; 10.6084/m9.figshare.11859810. ISBN: 978620-0-47168-0. EAN: 9786200471680.

Saleh, A.A., Rashad, A.M., Hassanine, N.N., Sharaby, M.A. and Zhao, Y., 2019. Comparative analysis of IGFBP-3 gene sequence in Egyptian sheep, cattle, and buffalo. BMC research notes 12,623 .

Saleh, A.A., Rashad, A.M. Sharaby, M.A., 2019b. Study of IGFBP-3 gene in Egyptian Farm Animals. LAMBERT Academic Publishing. DOI; 10.6084/m9.figshare.11859783. ISBN: 978-620-0-44301-4. EAN:9786200443014.

Saleh, A.A., Rashad, A.M., Hassanine, N.N., Sharaby, M.A. and Zhao, Y., 2020. Traditional Versus Modern Methods For Fertility Evaluation. LAMBERT Academic Publishing. DOI; 10.6084/m9.figshare.11859975. ISBN: 978-620-0-50365-7. EAN:9786200503657.

Sambrook, J. and Fritsch, E., 1997. Maniatis. 1989. Molecular cloning: a laboratory manual. Cold Spring Harbor Laboratory Press, Cold Spring Harbor, NY.

Sankhyan, V., Thakur, Y. and Dogra, P., 2019. Genetic polymorphism in IGF-1 gene in four sheep and goat breeds and its association with biometrical traits in migratory Gaddi goat breed of western Himalayan state of Himachal Pradesh, India. Indian Journal of Animal Research DOI 10.

Sarmah, R., Laskar, S., Nahardeka, N., Borah, P., Das, B. and Borkalita, L., 2019. Polymorphism of insulin-like growth factor-i gene and their association with weight at different age in Assam hill goats.

Shafey, H., Mahrous, K., Hassanane, M., Mordy, M.A. and Rushdi, H., 2014. Genetic polymorphism of myostatin and insulin-like growth factor binding protein-3 genes in Egyptian sheep breeds. Global Veterinaria 13, 419-424.

Sharma, A., Dutt, G., Jayakumar, S., Saroha, V. and Dixit, S., 2014. Sequence characterization and genetic variability analysis of GHR, IGF1, and IGFBP-3 genes in nine Indian goat breeds. Journal of applied animal research 42, 361-365.

Splaine, C.A., Hoffman, M.L., Jones, A.K., Pillai, S., Zinn, S.A., Govoni, K.E. and Reed, S.A., 2019. PSI-19 Poor maternal nutrition during gestation alters placental IGF-I, IGF-II, and IGFBP-3 mRNA expression in sheep. Journal of Animal Science 97, 255-255.

Tester, M. and Langridge, P., 2010. Breeding technologies to increase crop production in a changing world. Science 327, 818-822.

Veldhuis, J.D., Anderson, S.M., Shah, N., Bray, M., Vick, T., Gentili, A., Mulligan, T., Johnson, M.L., Weltman, A. and Evans, W.S., 2001. Neurophysiological regulation andtargettissue impact of the pulsatile mode of growth hormone secretion in the human. Growth Hormone \& IGF Research 11, S25-S37.

Wall, A., Juengel, J., Edwards, S. and Rendel, J., 2018. The economic value of replacement breeding ewes attaining puberty within their first year of life on New Zealand sheep farms. Agricultural Systems 164, 38-46.

Yousefi, S. and Azari, M.A., 2012. Genetic effect of growth hormone gene on yearling weight and wool traits in Zel sheep (Brief Report). Archives Animal Breeding 55, 303-306. 
Yousefi, S., Shahmohammadi, L., Azari, M.A., Zerehdaran, S. and Dehnavi, E., 2013. Survey of FecXL Locus of BMP15 Gene and Growth Hormone (GH) Gene and Their Effects on Lambing Rate in Zel Sheep. Iranian Journal of Applied Animal Science 3. 


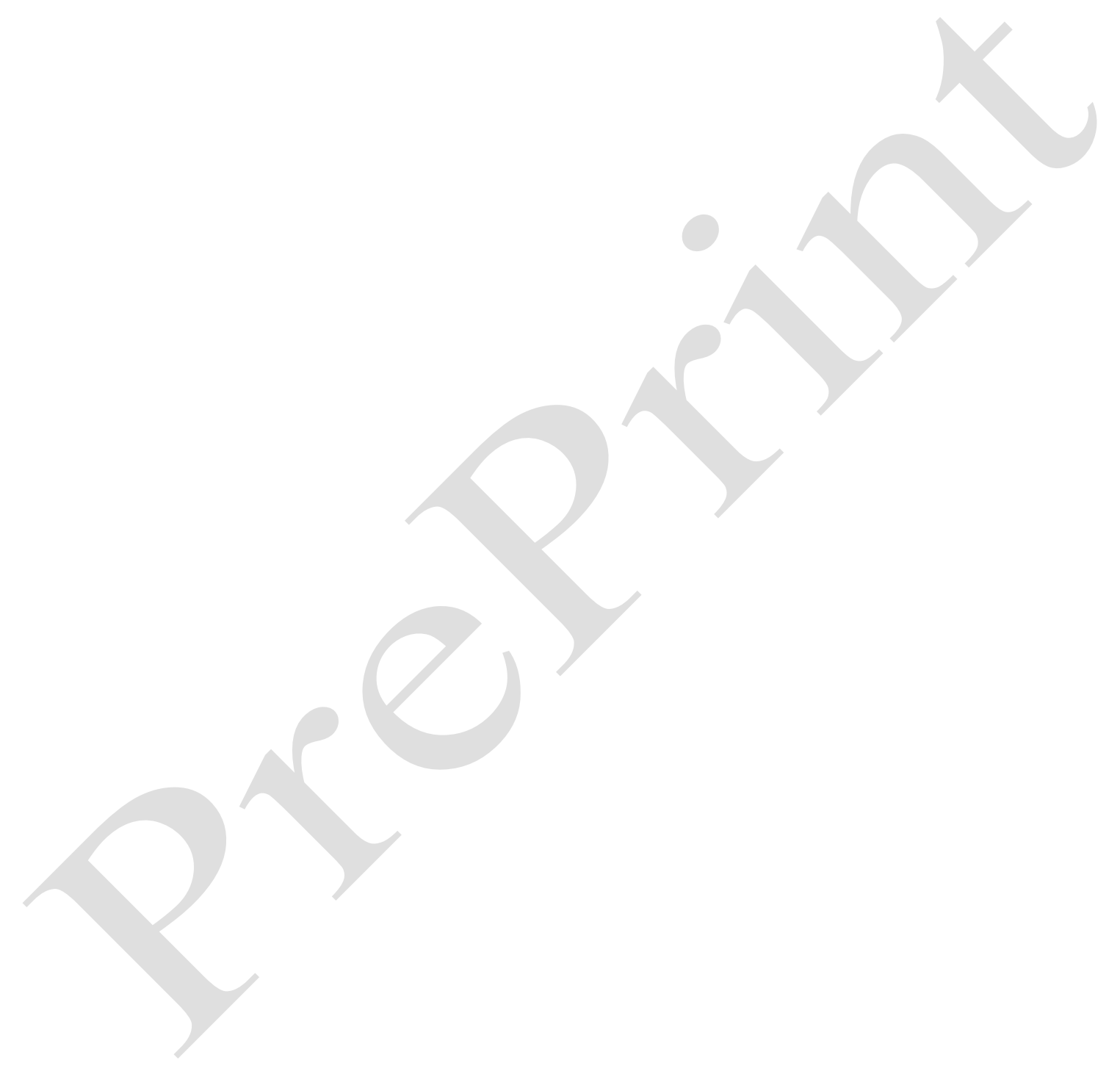




\section{Figures}
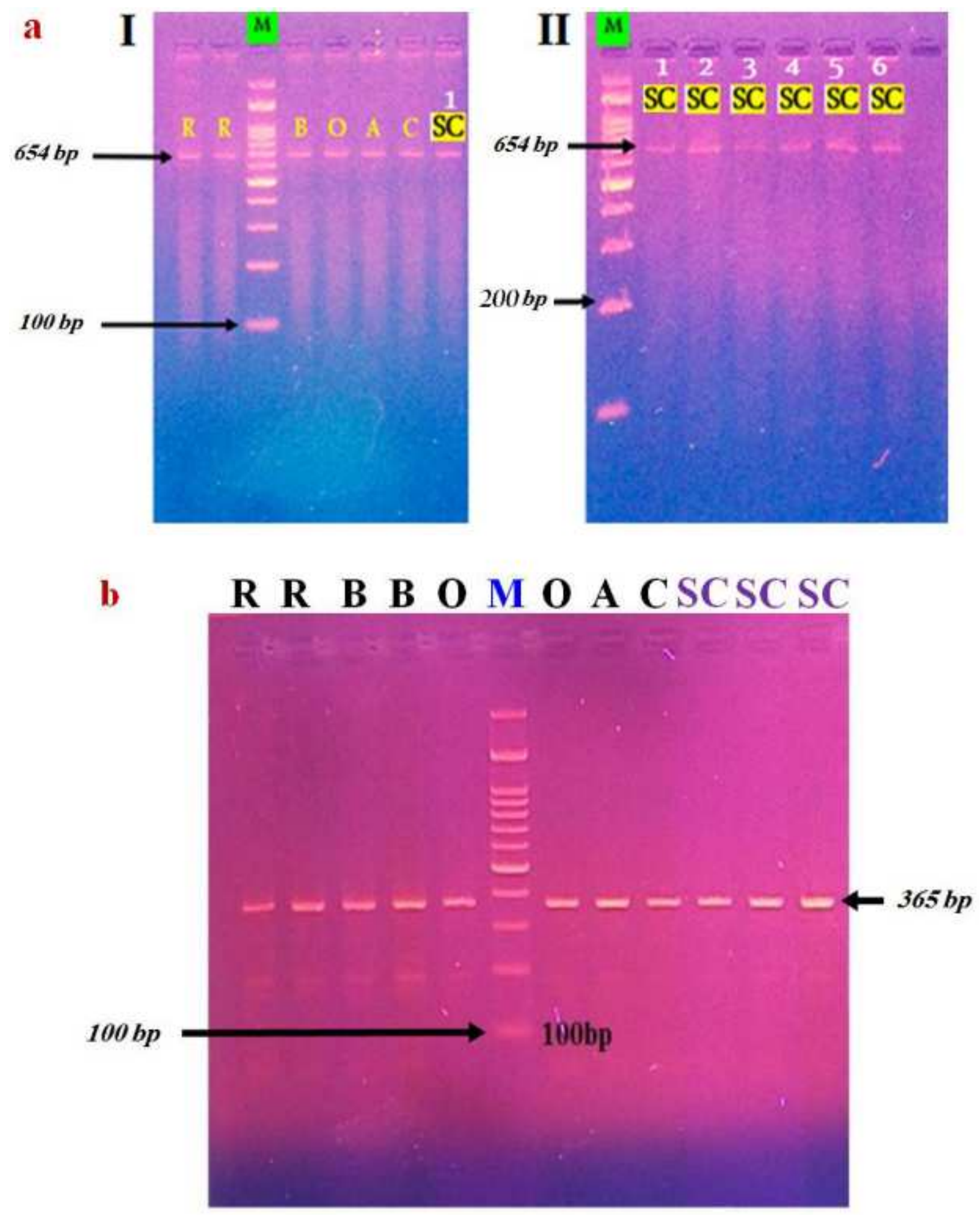

Figure 1

(a) I-Purified PCR product of IGFBP-3 gene from Rahmani (R), Barki (B), Ossimi (O), Rahmani X Barki cross (C), and Awassi (A)/Awassi X Suffolk cross (SC), M;100 bp DNA ladder and II- Purification of IGFBP3 gene (654bp) from Awassi X Suffolk cross (SC), M; DNA ladder with 100 bp. (b) PCR amplification of 
GH gene from genomic DNA of Rahmani (R), Barki (B), Ossimi (O), Awassi (A), Rahmani X Barki cross (C), and Awassi X Suffolk cross (SC), M;100 bp DNA ladder.

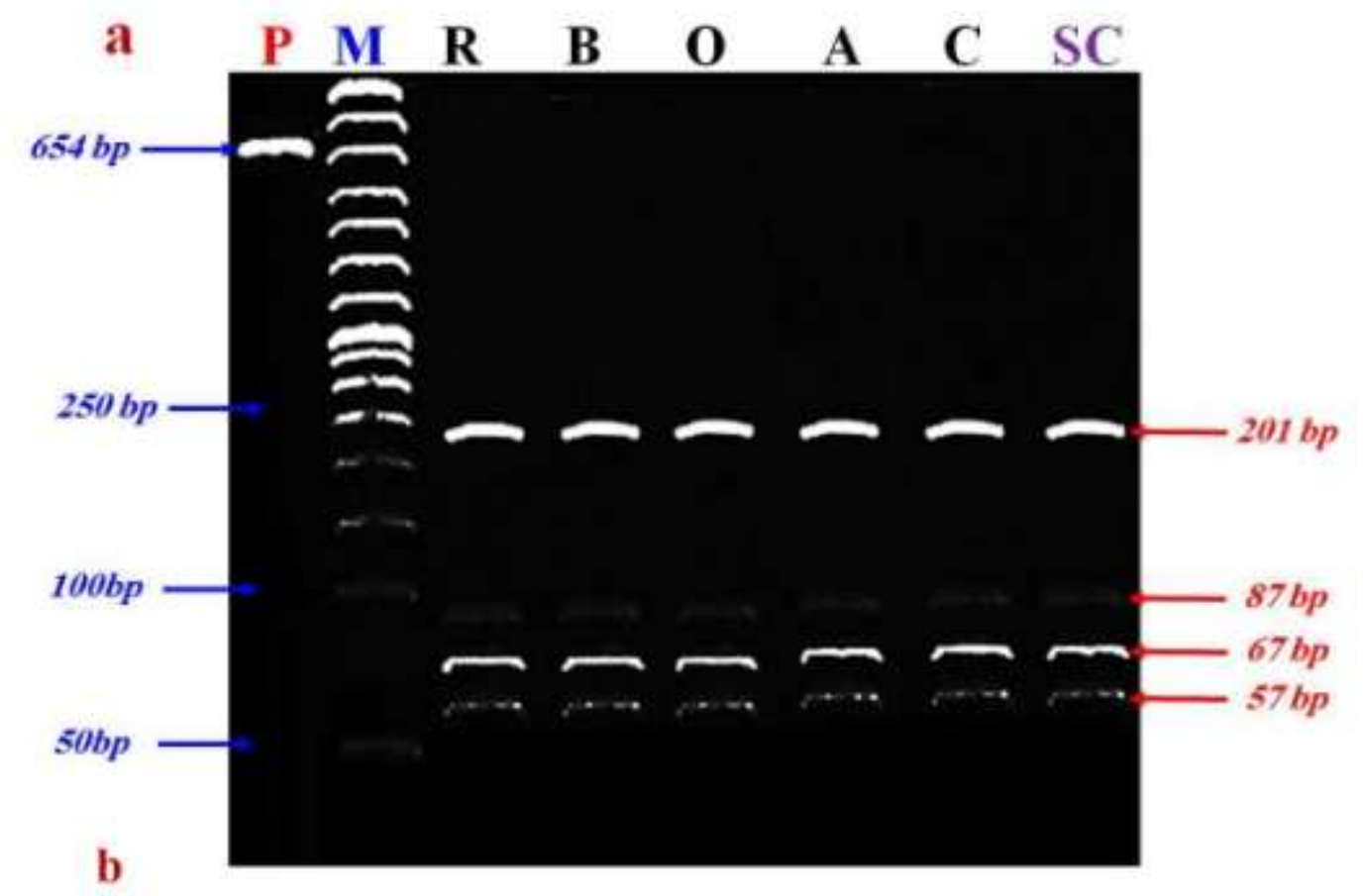

\begin{abstract}
CCAAGCGTGAGACAGAATCCGTAAGAGCTTTTCCTCTTGTTGTTGTGGGG GTGGG^CCCACCTGGGCTGGGTATCCAGAGATCACAGGGTCACCATTGAC TCAAGAGCCCAGCAGTTACTCCAAACCTGGTGCTGATGCACCAAGCAGCT GTGAGCCCCTCCTACAGAAGGGATATTGACCCTCCCCTGTGGCAGAGATC CCTTGAGAATCAGGGTACTGCTCTTCAGACCTCTGCTGGGCAGAGCAGTG TTCTCCCAAAGCTGG ${ }^{\wedge}$ CCTCTTTTTGTTCACTTGG $^{\wedge}$ CCTCTGAGTGG^CCTG $^{\wedge}$ GCCTGTGTGCCCCTGTCCCAGTTCTATGGCTTGCCCTGGGGAATCATGAGA GAGACAGGGGGCTGTGGCTGGCATCTGCATGGGAACGGTGACAACTAAA TCAGACAAAAGATACTCGAGGAGCACATGGTCAGTTCCCTGGGTGTTATG GGGTTTTATCAAACACAGAGTTCCCAGGTAACCCGTCCCTCCTCCCCGGG $\mathrm{GG}^{\wedge} \mathrm{CCAGGTTGCCGGGAAATGGAGGACACACTGAACGG}^{\wedge} \mathrm{CC}^{\wedge} \mathrm{TCAAGTTCC}$ TGAACACACTCAGCCCCAGGG^ CCATCCACATTCCCAACTGTGACAAGAA GGGCTTACTCGAGGAGGCACCTAACAACGACCTCATCAATTCTCGCTCCT ATCGG
\end{abstract}

\title{
Figure 2
}

(a) The PCR products of the IGFBP-3 gene from genomic DNA of tested sheep breeds digested by Haelli; Rahmani (R), Barki (B), Ossimi (O), Rahmani X Barki cross (C) and Awassi (A)/Awassi X Suffolk cross (SC). M, 50 bp DNA ladder, P; PCR product for IGFBP-3. The digestion with Haelll revealing a single pattern only for 8 DNA fragments sized 201, 201, 87, 67, 57, 18, 16 and 7 bp for IGFBP-3 gene. The restriction fragments with sizes; 18,16 and 7 bp were not seen on the gel. (b) A 654 bp sequence of IGFBP-3 gene of studied sheep breeds (NCBI accession no. MG738671.1). 


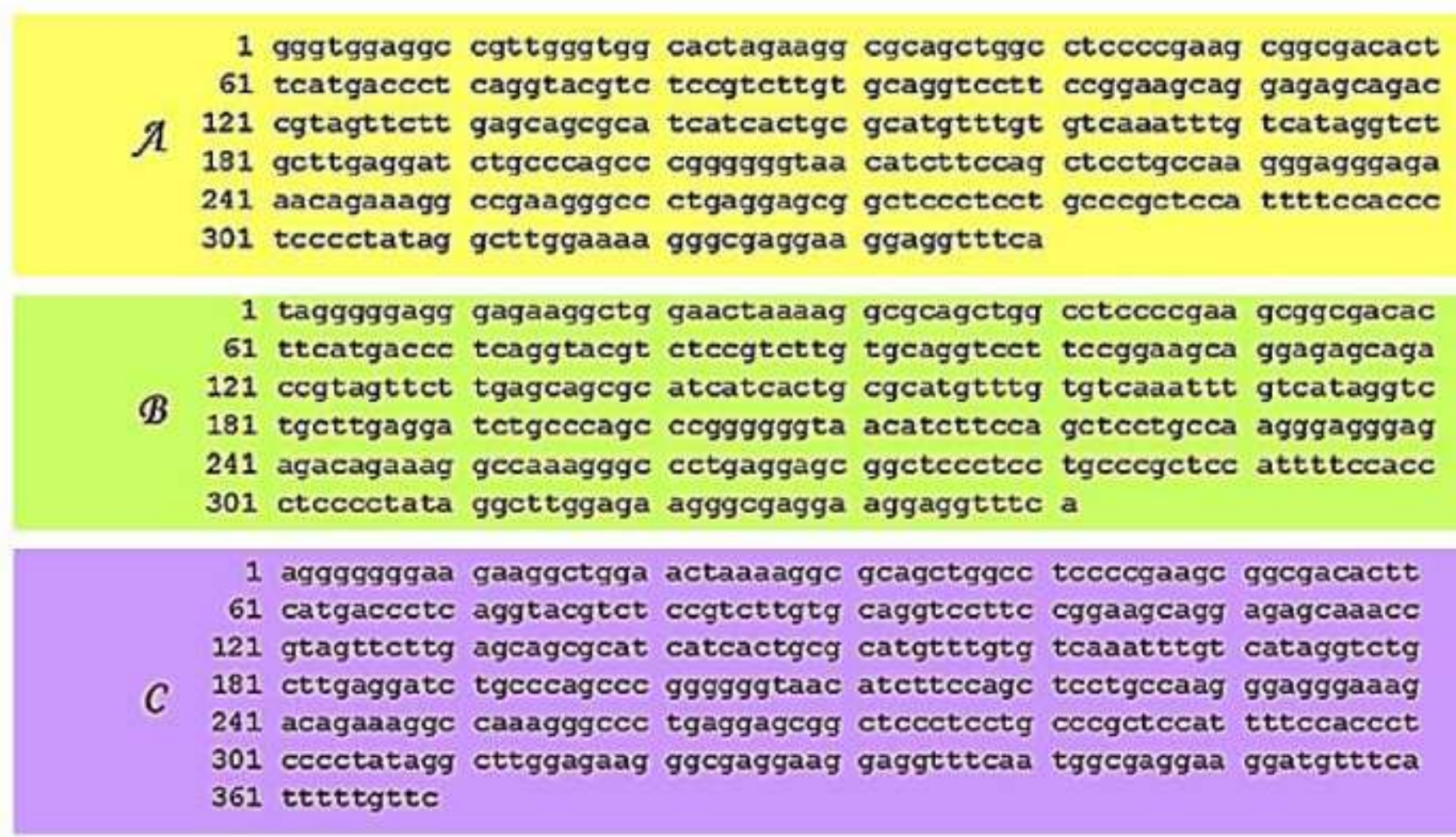

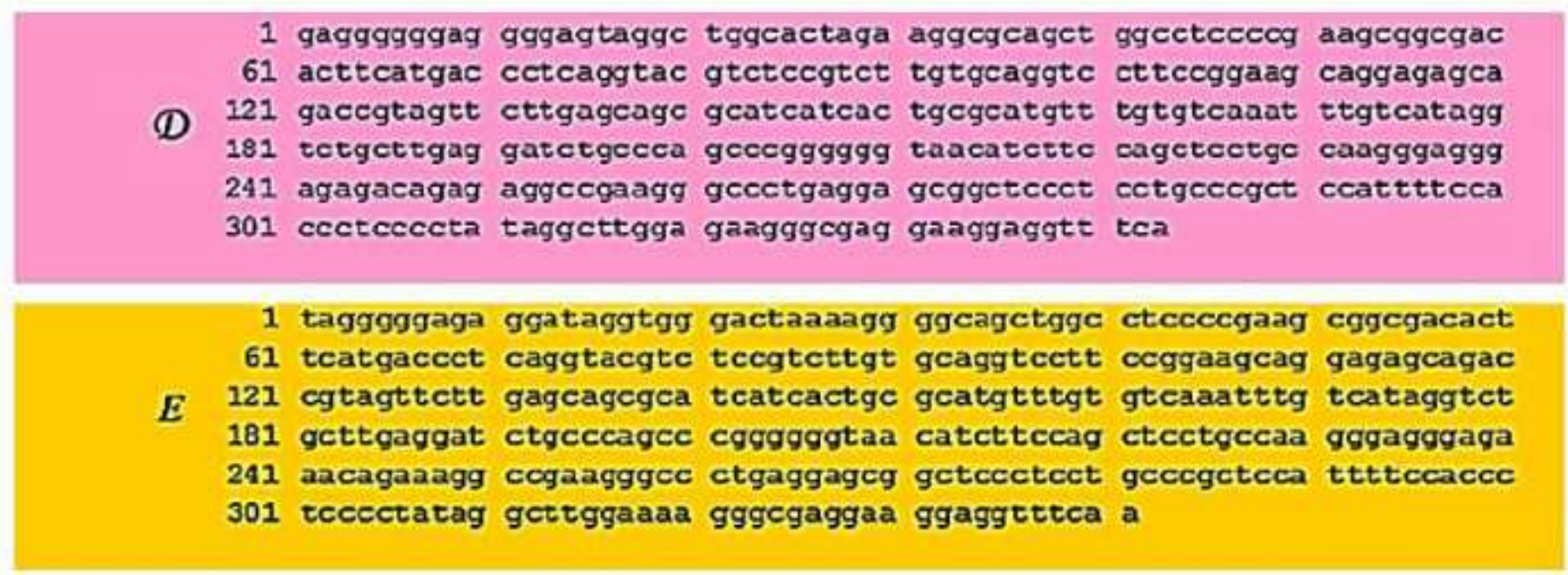

\section{Figure 3}

(A) A 365 bp sequence of GH gene of Rahmani breed (NCBI accession no. KP893631.1), (B) A 365 bp sequence of GH gene of Barki breed (NCBI accession no. KP893632.1), (C) A 365bp sequence of GH gene of Rahmani X Barki crossbreed (NCBI accession no. KP893634.1), (D) A 365 bp sequence of GH gene of Awassi/Awassi X Suffolk cross (NCBI accession no. KP893633.1), (E) A 365 bp sequence of GH gene of Ossimi breed (NCBI accession no. KP893635.1). 
1

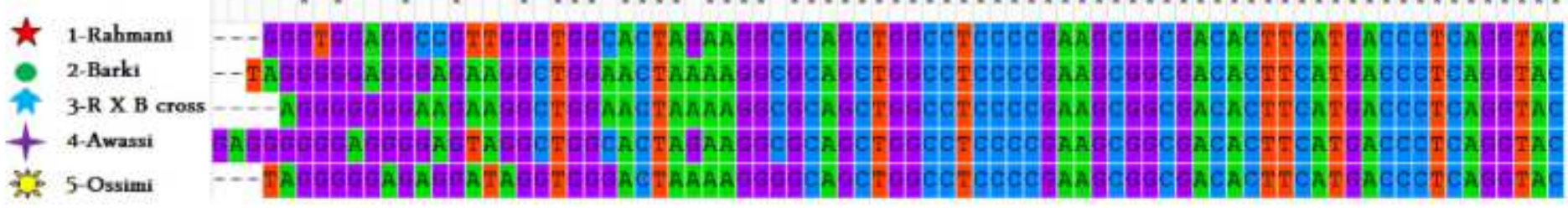

81

160

\$ 1-Rahmani

- 2-Barki

14 3-R X B cross

+ 4-Awassi

औै 5-Ossim

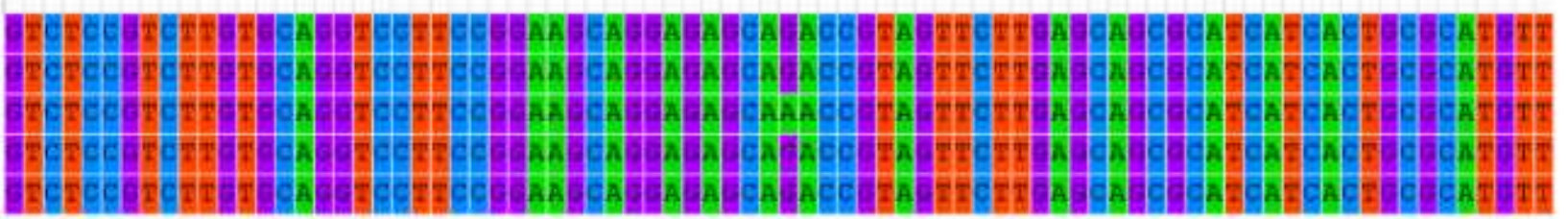

161

240

1-Rahmani
2-Barki
A-R X B cross
+ 4-Awassi
tैe 5 -Ossimi

…

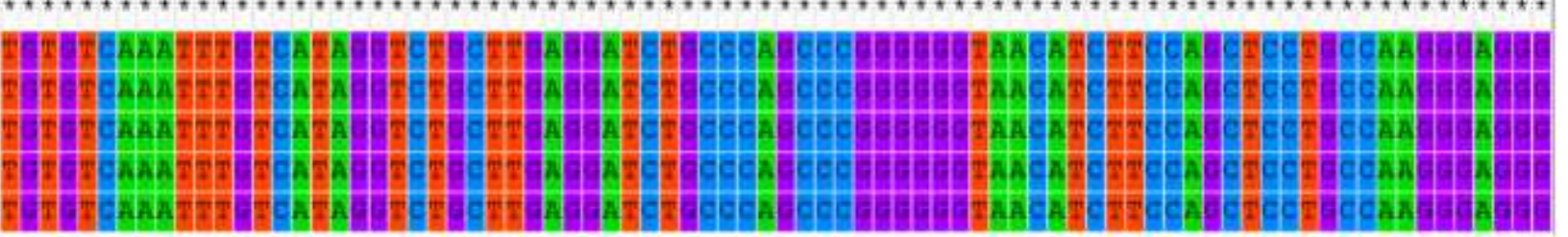

241

320

1) 1-Rahmani

- 2-Barki

1ै 3-R X B cross

$+\quad$ 4.Awassi

\%ै. 5-Ossimi

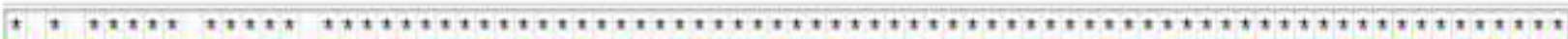

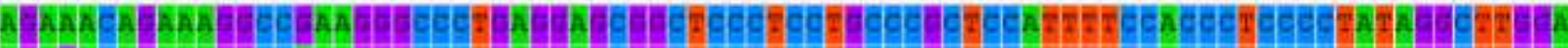

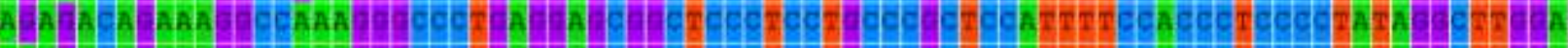

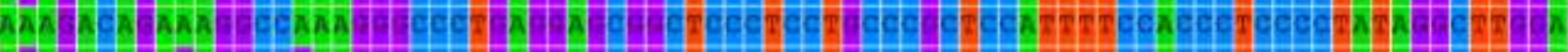

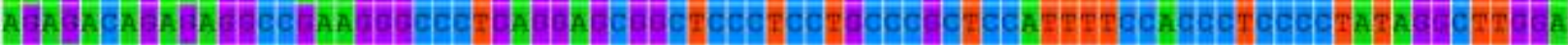

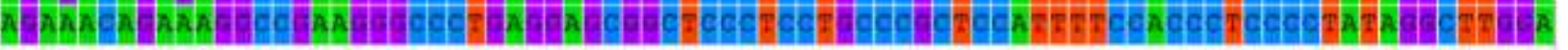

321

375

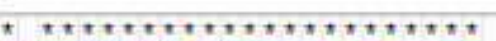

1-Rahmani
2-Barki
At 3-R X B cross
+ 4-Awassi
\%o 5 -Ossimi

BAAA

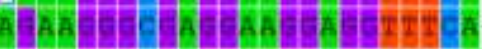

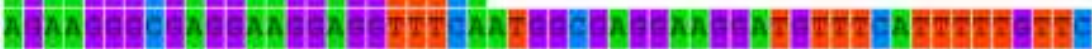

A A AA

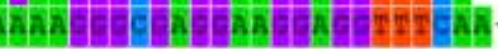

\section{Figure 4}

Nucleotide sequence comparison of amplified GH gene of tested sheep breeds. 


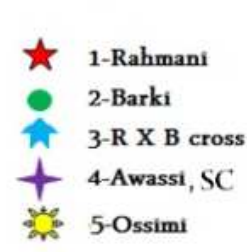

\section{3}

125
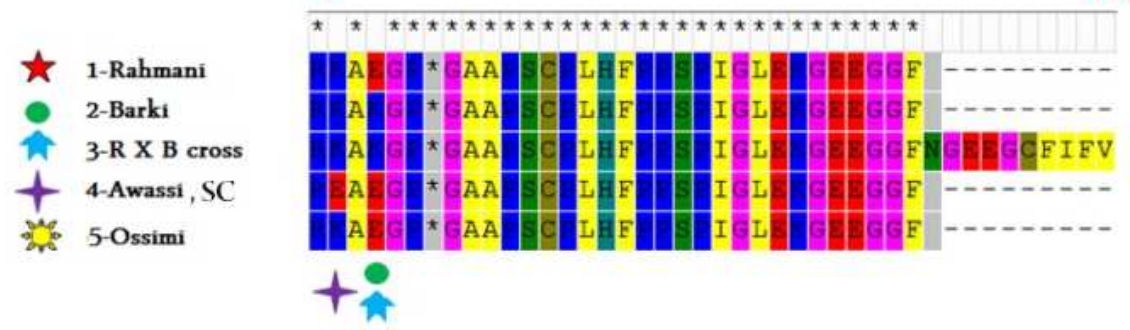

\section{Figure 5}

Comparative analysis of amino acid sequences of GH gene of tested sheep breeds. 